\title{
Transparency Standards in International Investment Agreement Negotiations: A Chinese Lawyer's Perspective on the UNCITRAL Rules
}

\author{
Qingjiang Kong* \& Yilin Wang **
}

The 47th Session of the UNCITRAL finalized the draft Convention on Transparency in Treaty-based Investor-State Arbitration. It aims to provide a mechanism to allow the UNCITRAL Rules on Transparency to be applied to investment dispute arbitrations mandated by investment treaties concluded before April 1, 2014. This paper intends to examine these UNCITRAL Rules on Transparency and the draft Convention on Transparency. It is particularly in contrast with the relevant rules in the NAFTA, the U.S. Model BIT 2012 and the ICSID Rules 2006, to see if transparency can be enhanced in treaty-based investor-State arbitrations and to extrapolate the implications of the Rules on Transparency and the draft Convention for China's strategy in BIT or FTA negotiations amid the trendy advancement of transparency standards.

Keywords: Rules on Transparency, Transparency Convention, Treaty-based investor-State disputes arbitration; Arbitration rules

\section{Introduction: Why is Transparency Questioned in Investor-State Arbitrations?}

Foreign direct investment ("FDI") was booming in the late 1990s, with the in-

\footnotetext{
* Professor at China University of Political Science ("CUPL") and Law and the Collaborative Innovation Centre for Territorial Sovereignty and Oceanic Rights. B.Sc.(Nanjing), LL.M.(ECUPL), Ph.D.(Wuhan). The authors wish to thank the editors for their remarkable work. The authors wish to thank the editors for their remarkable work. http://orcid.org/0000-0002-2168-1410 The author may be contacted at: qkong2000@cupl.edu.cn

** Graduate student at China University of Political Science and Law.
} 
crease in bilateral and multilateral agreements. Subsequently, investment disputes began to surge, altering the landscape of the FDI regulation. ${ }^{1}$ By the end of 2013, the number of bilateral investment treaties ("BITs") and free trade agreements ("FTAs") containing provisions on investment (hereinafter international investment agreements, or "IIAs") were as many as $3200,{ }^{2}$ more than 2300 of which are in force today. ${ }^{3}$ These patchworks of IIAs have interwoven with one another, dubbed as "a spaghetti bowl." Arguably, the boom in international investment activities, combined with an increasingly dense international network of treaties providing for investor-State dispute settlement ("ISDS") arbitrations, gave rise to the massive outbreak of treaty-based investor-State dispute arbitrations, i.e., investment arbitrations. ${ }^{5}$ The UNCTAD World Investment Report 2014 indicated that investors had, by far, launched at least 568 known ISDS cases pursuant to IIAs. ${ }^{6}$

Arbitration of investor-State disputes is the key to understanding the investment relationship between countries that are governed by IIAs. However, it is not without flaws. One of the controversial problems in the arbitral proceedings of investment disputes is 'transparency.' A default to confidentiality and privacy in investment arbitrations has its historical origins from commercial arbitrations in accordance with the United Nation Commission on International Trade Law ("UNCITRAL") arbitration Rules or other arbitration rules of leading arbitration institutions. E.g., documents submitted to the arbitrators are kept confidential, hearings closed to the public and sometimes the public does not even know of the existence of such cases.

However, there is a counter-tension in the transparency debate, as well. The large number of arbitrations have raised the issue of transparency at the international level, which would guarantee a more accountable, democratic and legitimate system of global governance. ISDS thus could not ignore this general trend, considering its open nature of dispute settlement especially in international legal institutions such as the World Trade Organization ("WTO"), the International Court of Justice ("ICJ"), and other human rights bodies.

As the New York Times pointed out that: "The secret conference held by the arbitrators on Investor-State Disputes have reached arbitration awards that abolished a state's law, doubted the judicial system and challenged the environmental regulations," ${ }^{7}$ the ISDS mechanisms inclined to protect the investors' interests 
against the Host States, suggesting a large amount of compensation. Also, the sources of this compensation are undoubtedly originated from domestic revenue, the burden of which will ultimately fall on the general public, i.e., taxpayers. All of these will be detrimental to public interest, and most directly public purse.

Inspired by the notion of 'global governance' and concerns over the lack of judicial review over IIAs disputes arbitration, such ISDS mechanisms as the UNCITRAL and the International Center for Settlement of Investment Disputes ("ICSID") have gradually taken transparency standards into consideration in the end.

The primary purpose of this research is to examine transparency standards in international investment agreement through the UNCITRAL rules. This paper is composed of six parts including Introduction and Conclusion. Part two will overview the transparency standard. Part three will interpret the transparency standards in investment arbitration. Part four will analyze the Transparency Convention. Part five will discuss the UNCITRAL Rules on Transparency. Part five, as a Conclusion, will discuss the implications of the UNCITRAL Rules on Transparency and its application to China.

\section{Overview of Transparency Standard in InTERNATIONAL InVESTMENT AgREement}

\section{A. Global Governance: a Catalyst for Transparency Standards}

As the Cold War ended, the notion of 'global governance' began to "emerge as the evolving regulatory structures that demands for transparency, consultation, participation, reasoned decisions and review mechanisms to promote accountability and good governance." "A high-profile characteristic of the global governance is 'good governance' to protect public interest in a broader sense." To build good governance, transparency standards, inter alia, are regarded as fundamental procedure and rules. Joan Ribeiro, the head of UNCITRAL-RCAP reiterated that: "Transparency lies as the very foundation of good governance."

In addition, global governance encompasses "all kinds of public or private individuals or institutes." "11 Noticeably, non-governmental organizations ("NGOs") have assumed greater responsibilities in global public affairs, successfully safe- 
guarding public interest in several arenas. It is worth mentioning that in some investor-State Investment arbitrations, ${ }^{12}$ NGOs would be welcomed as amici curiae to submit specialized information pertaining to public interest concerns in arbitrations. $^{13}$

\section{B. Public Scrutiny: A Substitute for Judicial Review}

In commercial arbitration, the award is final and binding upon both parties. Likewise, in the arbitration of treaty-based investment disputes, neither an appellate mechanism nor any other review system may work as effectively. In certain cases, in order to carry out judicial review, domestic courts may be authorized to revoke the award pursuant to the Convention on the Recognition and Enforcement of Foreign Arbitral Awards (hereinafter New York Convention). The ICSID Convention has also set up an annulment system under Articles 50(1)(c)(iii) ${ }^{14}$ and 52, "though flawed with some mis-functions: no remedies for participants and no effective reviewing institute." 15

Investment arbitrations need judicial review because it implicates public interests, extending beyond self-interest of both parties, whereas commercial arbitrations only relate to the interests of individuals. Briefly, the 'publicity' would distinguish investor-State dispute arbitrations from commercial arbitrations. Without an appellate system and judicial review, investment arbitrations may undermine the interest of millions of people. However, appellate review would postpone decision-making, going against the efficiency of arbitration. To weigh public interest vis-à-vis arbitral efficiency, transparency should be highlighted so that the public scrutiny can become the substitute for judicial review.

\section{Transparency Standards in InVestment Arbitrations: Its Evolutional Interpretation}

'Transparency' is defined as "openness, which is used of financial disclosures, organizational policies and practices, lawmaking, and other activities where organizations interact with the public." ${ }^{16}$ It is also referred to as "an essential condition for those operating in a market, which ensures that the rules to which they are subject are made obvious. Generally, it ensures that the reasons behind 
measures and the applicable regulations are clear to all, so that all are treated fairly." ${ }^{17}$ From the authors' perspective, 'transparency' is summarized as openness and public participation.

When it comes to treaty-based investor-State arbitrations, the confidentiality principles of commercial arbitrations are generally applicable, leaving no room for public involvement or not giving due importance to transparency. ${ }^{18}$ Only under extreme circumstances where both parties reached consensus on publicizing the arbitration can the proceedings be made available to the public. ${ }^{19}$

The pioneering practice of transparency in treaty-based investment arbitrations dates back to the 1994 NAFTA. Dealing with investment, Article 1137(4) of the NAFTA (Chapter 11) annexed thereto governs the publication of awards as follows: "For arbitrations involving the United States or Canada, either disputant may make the award public; for arbitral proceedings involving Mexico, the applicable arbitration rules will govern. ${ }^{20}$ In 2001, as a step forward, the Contracting Parties to the NAFTA issued a Note of Interpretation specifying that:

Nothing in Chapter 11 itself precluded a NAFTA party from providing public access to documents submitted to or issued by Chapter 11 tribunals ${ }^{21} \ldots$ The Note of Interpretation also set forth the NAFTA parties' agreement to make such documents available to the public in a timely manner, subject to certain exceptions, including for the protection of confidential business information and where disclosure would be prohibited under applicable arbitral rules ${ }^{22} \ldots$ In subsequent BITs and FTAs concluded by the NAFTA parties, the countries have gone even further to ensure openness of investor-State dispute settlement by including provisions on transparency directly in the treaties (as opposed to Notes of Interpretation). ${ }^{23}$

The NAFTA's move gave impetus to Canadian and American templates of BITs, as manifested in Article 38(3) of the 2004 Canada's Foreign Investment Promotion ${ }^{24}$ and Protection Agreement ("FIPA") and Article 29 of 2004 U.S. Model $\mathrm{BIT}^{25}$ respectively. Later, this trend was mirrored in Article 94(4) of the JapanMexico Free Trade Agreement and Chapter 11 of the ASEAN-Australia-New Zealand Free Trade Area. ${ }^{26}$ To name just a few, the trend of transparency seems irreversible.

Unlike the NAFTA, which is per se an investment treaty between sovereign 
States, the ICSID Convention is a mechanism constructed solely for investment disputes. To echo with this trend, a series of amendments enacted in 2006 updated the ICSID Arbitration Rules for augmentative transparency. Ordinary clauses of transparency such as "open hearings, amicus curiae briefs and publication of awards $" 27$ have been structured into the 2006 revision of the ICSID Rules. They were then "tested in several recent disputes where transparency was demanded, for example, the Amco v. Indonesia and the Biwater v. Tanzania. ${ }^{28}$ Hence, the obedience of confidentiality in investment arbitration under the auspices of the 1956 ICSID Convention has been obscured by the request for transparency. ${ }^{29}$

Finally, the UNCITRAL was aware that it has lagged behind its peer institutions in the progress of transparency reform. For the past few years, ${ }^{30}$ the UNCITRAL Working Group II (Arbitration and Conciliation) listed transparency reform on the agenda, ${ }^{31}$ and eventually harvested a new array of transparency rules such as the UNCITRAL Rules on Transparency in Treaty-based InvestorState Arbitration (hereinafter Rules on Transparency). ${ }^{32}$ The 46th session of the UNCITRAL Commission in 2013 adopted these Rules on Transparency, together with the UNCITRAL Arbitration Rules. ${ }^{33}$ Both the Rules on Transparency and the UNCITRAL Arbitration Rules of 2013 came into effect on April 1, 2014.

Following the introduction of the Rules on Transparency there were vigorous debates over the application of IIAs. ${ }^{34}$ At the 46th session, the Commission recorded:

a consensus to entrust the Working Group II with the task of preparing a con-
vention on the application of the Rules on Transparency to existing investment
treaties (Transparency Convention). It took into account that the aim of the
Transparency Convention was to give those States that wished to make the
Rules on Transparency applicable to their existing investment treaties an ef-
ficient mechanism to do so, without creating any expectation that other States
would use the mechanism offered by the Transparency Convention.

At the 47th Session of the UNCITRAL, the draft Convention on Transparency was finalized. ${ }^{36}$ Insofar as the definition of transparency in investment disputes is concerned, the UNCTAD published a Transparency Pink Series Paper in 2004, stating that: 
The increasing exploration of transparency obligations directed at investors marks a significant shift in recent notions of transparency in IIAs. Extending transparency obligations to corporate disclosure can also promote a better understanding between investors and host State authorities regarding their expectations about disclosure on the side of the investor. Such an approach may also protect the interests of relevant communities in the host State by providing information on the past practices of potential investors. ${ }^{37}$

Generally, transparency standards in a treaty-based investor-State arbitration may contain: public notice of commencement of proceedings, public access to documents, the participation of non-disputing parties or amicus curiae, the confidential information excluded from openness, open hearings and the publication of final awards. ${ }^{38}$

\section{The Transparency Convention}

\section{A. Relationship between Existing IIAs and the Transparency Convention} With regard to the relationship between existing IIAs and the Transparency Convention, Working Group II underwent several rounds of discussions, and decided on the opt-in approach for existing treaties and the opt-out approach for the future treaties. ${ }^{39}$ The Rules on Transparency draw a line distinguishing treaties concluded after a particular date from those prior to it. This date was pegged as April 1, 2014 to align with the effectiveness of Rules on Transparency and the 2013 UNCITRAL Arbitration Rules. ${ }^{40}$ As such, the treaties concluded before April 1, 2014 are referred to as "existing investment treaties" or 'existing treaties'; correspondingly, treaties concluded after April 1, 2014 are 'future treaties. ${ }^{41}$

\section{Existing Treaties}

In existing treaties, applications of the Rules on Transparency are subject to the consent by disputing parties or treaty parties on a case-by-case basis. The opt-in approach became the central issue of many dissenting opinions. Delegates from the US and Canada, e.g., opined that the opt-in approach would derogate the impact of Rules on Transparency. ${ }^{42}$ Rachel Davis maintained: "U.N. Secretary-General's Special Representative on Business and Human Rights worried that this would re- 
sult in an undesirable two-tiered set of arbitrating practices and bring about a disjunctive situation in relation to the application of the Rules on Transparency." ${ }^{, 43}$ In other words, this is a situation of "striking an optimal balance in underlying policy concerns with maximizing widespread adoption of transparency standards versus preserving parties' intent in the arbitration process. ${ }^{, 44}$ Working Group II, however, adopted this approach by reasoning that the application of Rules on Transparency will "constitute an amendment to the treaty provision on dispute settlement, which could not be done without the agreement of treaty parties, who are the 'masters' of their treaties." ${ }^{45}$

Particular attention is shed upon the relationship between the Transparency Convention and existing multilateral investment agreements where only some of the Contracting Parties of the multilateral investment agreement are signatories to the Transparency Convention. ${ }^{46}$ The Contracting Party shall be free to retain the standard that is different from that set forth under the Rules on Transparency, unless it has expressly made the Rules on Transparency applicable to the arbitrations of investor-State investment disputes between itself and other contracting Parties of the Transparency Convention. ${ }^{47}$ This belief is based on the fact that IIAs are the result of long and deliberated negotiations between contracting parties such like Sino-Canada bilateral investment agreement, which took about two decades. ${ }^{48}$ Negotiated investment treaties are supposed to address all the concerns of the contracting parties and have struck equilibrium or compromises among all contracting parties or more than two contracting parties after taking all tradeoffs into consideration. Therefore, the existing IIAs shall not be affected unless the contracting parties to those treaties have expressly applied the Rules on Transparency to the arbitrations of investor-State investment disputes initiated under the exiting investment treaties. ${ }^{49}$

\section{Future Treaties}

When it comes to future treaties, the application of Rules on Transparency will become a default applicable rule, i.e., the opt-out approach. Under the opt-out approach, "the transparency standards would apply to future treaties referring to the UNCITRAL Arbitration Rules, unless a reference to a different version of the Rules was made in the treaty." ${ }^{, 50}$

In a nutshell, with regard to the relationship between existing IIAs and the 
Transparency Convention, considering that the application of Rules on Transparency to future treaties is automatic upon references to the UNCITRAL Arbitration Rules in the IIAs, the Transparency Convention helps solve application problems of the Rules on Transparency to existing treaties. Article 1 of the Transparency Convention stipulates:

This Convention applies to arbitration between an investor and a State or a regional economic integration organization conducted on the basis of an 'investment treaty ${ }^{51}$ concluded before 1 April $2014 .^{52}$

\section{B. Unilateral Offer to Arbitrate under the Rules on Transparency}

As per Article 2 of the draft Transparency Convention, the UNCITRAL Rules on Transparency may be applied into the following two ways: (a) bilateral or multilateral application; and (b) unilateral offer of application.

In the first scenario, the Rules on Transparency shall apply when both the investors' home State and the respondent State are Contracting Parties to the Transparency Convention. Article 2 of the Transparency Convention presents the following conditions: only if "the respondent is a Party that has not a relevant reservation under Article 3(1)(a) or (b), ${ }^{53}$ and the claimant is of a State that is a Party that has not made a relevant reservation under Article 3(1)(a)., ${ }^{54}$

In the other scenario, debates have been raised over whether a unilateral offer of application shall be added to the scope of applications in order to maximally apply the Rules on Transparency. ${ }^{55}$ Anyway, the draft Transparency Convention ended with providing a possibility for "investors to initiate a claim under a relevant investment treaty, where that investor's home State was not a party to the Transparency Convention, for that investor to accept the application of the Rules on Transparency., ${ }^{, 6}$ Therefore, in Article 2, paragraph 2 of Transparency Convention, such clauses are embedded as follows:

The UNCITRAL Rules on Transparency shall apply to an investor-State arbitration in which the respondent is a Party that has not made a reservation relevant to that investor-state arbitration under Article 3(1), and the claimant agrees to the application of the UNCITRAL Rules on Transparency. ${ }^{57}$ 


\section{Applicability of the Transparency Rules to Arbitrations under those other than UNCITRAL Arbitration Rules}

If the Transparency Convention had merely applied to the treaty-based arbitrations under the UNCITRAL Arbitration Rules, the disputants might evade the binding force of transparency standards. Equally, upon consultations with arbitral institutions in the course of drafting the Rules on Transparency, the delegation groups reckoned that: "The Rules on Transparency worked in conjunction with other institutional rules. ${ }^{, 58}$ So it was then included in Article 2(2) of the Transparency Convention, under which the Rules on Transparency will apply to an investor-State arbitration, regardless of its initiation under the UNCITRAL Arbitration Rules. Granted, reservations, if needed, may be rendered to preclude the application to other arbitration rules than the UNCITRAL Arbitration Rules, as hinted by Article 2(3) ${ }^{59}$ of the Transparency Convention. ${ }^{60}$

\section{Applicability of the Transparency Standards in Case of MFN Clause}

Another concern of the Transparency Rules would be extending to whether a 'Most-Favored-Nation' ("MFN") clause in an investment treaty could be invoked by carving them out of certain investment treaties from the Transparency Convention. Suppose that there are three Contracting Parties to the Transparency convention, among which Party A has excluded the application of the Transparency Convention in its investment treaty with Party B, but not with Party C. Possibly, an investor in Party $\mathrm{C}$ can invoke the MFN clause to avoid the application of the Transparency Convention, in which the MFN entitles it to apply confidential arbitration according to the non-transparent regime under the investment treaty between Parties A and B.

Article 2(5) of the Transparency Convention responds to this conflict by clarifying that: "The Parties to this Convention agree that a claimant may not invoke a MFN provision to seek to alter the application [or non-application] under this Convention of the UNCITRAL Rules on Transparency." ${ }^{, 61}$ By definition, the Working Group managed to remove the possibility hidden in the Convention that might prohibit the application of the Rules on Transparency. Perhaps still, "the MFN clauses shall be applied to addressing the treatment of investors or promotion of investment rather than a procedural regime of transparency." 


\section{E. The Formulation of Reservations}

The Transparency Convention grants Contracting Parties the right to make reservations. The scope of reservations includes: (a) exclusion of specific treaties; (b) non-application of the Rules on Transparency when conducted under arbitration rules other than the UNCITRAL Arbitration Rules; (c) reservations on unilateral offers of application in Article 2(2) when the party is a respondent; and (d) reservations on accepting a revised version of the Rules on Transparency within six months. $^{63}$

Additionally, Article 4 reads: "Reservations may be made by a Party at any time." This clause has greatly impaired implementation of transparency standards. It is, however, in conformity with the principle of the Transparency Convention. In that case, transparency standards shall not interfere with the operation of about 3200 treaties concluded in the past, after considerable deliberations among parties. ${ }^{64}$

In order to determine application issues, we will probe into the provisions of the Rules on Transparency and make a comparison with the 2006 ICSID Rules and the dispute settlement provisions in IIAs such as the NAFTA.

\section{The UNCITRAL Rules on Transparency: CONTRAST WITH Relevant Rules IN IIAs AND Other Arbitral Rules}

\section{A. The UNCITRAL Rules on Transparency at a Glance}

The Rules on Transparency is composed of a set of procedural rules that provide for transparency and accessibility to the public of treaty-based investor-State arbitration. In particular, the Rules on Transparency include the following major provisions:

\section{Articles 2, 3 and 6: Publications of Documents and Open Hearings}

Articles 2 and 3 address the free publication of information and documents submitted to arbitration proceedings subject to certain safeguards, including the protection of confidential information. Under the Rules, information and documents in the arbitration process are made public. 
Each published case will include: the notice of arbitration, the response to the notice of arbitration, the statement of claim, the statement of defense, any further written statements or written submissions by a disputing party, a table listing all exhibits to those documents (if it has been prepared for the proceedings), any written submissions by the non-disputing treaty Party/Parties and by third parties, transcripts of hearings, where available, and orders, decisions and awards of the arbitral tribunal. ${ }^{65}$

At the "notice of arbitration" stage of proceedings, the following are being published: the name of the disputing parties, the economic sector involved, and the investment treaty under which the claim is being made. ${ }^{6}$

Further, expert reports and witness statements are being published upon request by any person to the arbitral tribunal, but subject to confidentiality provisions in the Rules on Transparency. ${ }^{67}$ Open hearings shall be also tackled here. ${ }^{68}$

\section{Articles 4 and 5: Third Party and Non-disputing Treaty Party Submissions}

Articles 4 and 5 deal with the amicus curiae briefs and submissions by nondisputing treaty Parties, respectively. Under certain criteria set out in the Rules, both third parties and non-disputing treaty parties can make submissions.

\section{Article 7: Exceptions to Transparency}

Article 7 provides for protection of confidential information. Under the Rules, arrangements will be made to prevent any confidential or protected information from being made available to the public. There are further safeguards in the Rules to ensure that such publication does not disrupt or unduly burden the arbitral proceedings, or unfairly prejudicice any disputing party. ${ }^{69}$

The Rules on Transparency are in the pursuit of a high degree of openness during proceedings. ${ }^{70}$ By this process, the public will have access to documents submitted, hearings will be open to the public, and interested parties will be able to render submissions to the proceedings. In other words, the Convention is presumed to have set out new transparency standards for investor-State dispute settlements. ${ }^{71}$ By comparing the UNCITRAL Rules on Transparency to the NAFTA, 2012 U.S. Model BIT and ICSID, the standards of these Rules on Transparency may be visualized. 


\section{B. Comparison among the Rules on Transparency, Other Arbitral Rules and Rules in IIAs}

\section{Publication of the Information}

Article 29(1) of the 2012 U.S. Model BIT articulated that 'the respondent' is liable to disclosure, while Article 22(1) of the ICSID Arbitration Rules require 'the secretariat' to publicize information in a reasonable way, when appropriate. Article A2(b) of the NAFTA Notes of Interpretation of Certain Chapter Provisions ${ }^{72}$ has adopted a vague expression in this regard. As such, the transparency repository operated by the UNCITRAL shall be deemed as more viable to bear the responsibility of publication. Practically speaking, the costs of establishing repository are taken into consideration since it may lift arbitration expenses that parties have to undertake. ${ }^{73}$ Anyhow, "this is a significant move of the UNCITRAL to promote transparency effectively.",

Besides, another innovative move that the UNCITRAL took was to categorize documents open to the public into the following three types: "(a) the documents that shall be made available; (b) the documents that shall be made available upon request by any person to the arbitral tribunal; (c) the documents that the tribunal has discretion over the publication." 75 This is because the UNCITRAL Rules is featured as mandatory openness, which is invisible in the ICSID mechanism and other IIAs, e.g., the 2012 U.S. Model BIT. More precisely, in ICSID mechanism, the information will be made available to the public when parties involved agree upon the openness. ${ }^{76}$ In the 2012 U.S. Model BIT request for openness by the parties would be accepted without discretion of the Tribunal. ${ }^{77}$

\section{Open Hearings}

Both the UNCITRAL Rules on Transparency ${ }^{78}$ and the 2012 U.S. Model BIT ${ }^{79}$ allow open hearings, yet other major arbitral rules remains ambiguous in this respect. If looking at the ICSID Arbitration Rules, arbitration hearings were invariably held behind closed doors. Therefore, tribunals began to manipulate their discretion over the open hearings via consultations with the parties, ensuring no disruption or no delay of the arbitrating proceedings. Famous cases in point are Methanex Corp. v. United States ${ }^{80}$ and Glamis Gold Ltd. v. United States. ${ }^{81}$ 


\section{The Position of Amicus curiae brief}

Amicus curiae brief, also known as "the Friend of the Court," is defined as "one who, as a bystander, may inform the court when the judge is doubtful or mistaken in a matter of law," escaped consideration or the legal matters which have escaped its notice and regarding which it appears to be in danger of making a wrong interpretation." ${ }^{83}$ There are now two major patterns of amicus curiae brief in the treaty-based investor-State arbitrations: the UNCITRAL Rules on Transparency and the 2006 ICSID Rules.

\section{The 2006 revision of ICSID Rules}

The pre-2006 ICSID Rules had been silent with respect to the amicus curiae question. However, tribunals have not been haunted by the silence, but boldly employed amicus curiae briefs in Suez/Vivendi. In that case, the tribunal unanimously contended that Article 44 of the ICSID Convention had granted the tribunal residual power to decide procedural question, and especially "the power to admit amicus curiae submissions from suitable non-parties in appropriate cases. ${ }^{, 84}$ Even so, it was not until the 2006 ICSID Rules that tribunals was authorized to accept amicus briefs in an explicit provision. The 2006 ICSID Rules require: "The tribunal to consult with the parties before deciding whether to allow the non-party submissions, but do not allow either or both parties together to veto the tribunal's decision on the matter." submission, a tribunal must contemplate a non-exclusive list of several factors stipulated in the ICSID Rules. ${ }^{86}$ The templates of Canada FIPA ${ }^{87}$ and the 2012 U.S. BIT ${ }^{88}$ have followed this ICSID practice.

\section{The UNCITRAL Rules on Transparency}

The Rules on Transparency did not employ amicus curiae brief to obtain a more comprehensive understanding of the texts in all legal documents. Instead, the Rules adopted a rather general term, "Submission by a third person." in the proceeding section, the UNCITRAL segregates third party submission from a non-disputing party to circumvent potential diplomatic protection that may be proposed by the non-disputing party. As such, "if the investor's home State were allowed to file a submission beyond matters of treaty interpretation, 
and to address matters of law, there would be a risk that the submission by the non-disputing State Party to the treaty might come very close to diplomatic protection." "90 It was early 2001 that the amicus curiae brief was introduced into the investment arbitrations, in Methanex Corp. v. United States. ${ }^{91}$

\section{Publication of Final Awards or Results}

The ICSID Rules state that the ICSID Secretariat must promptly include, in its publications, the excerpts of the legal reasoning supporting the award even when parties do not agree to ICSID's publication of the award itself. ${ }^{92}$ The UNCITRAL Rules on Transparency and the 2013 UNCITRAL Arbitration Rules request the publication of final reward in Articles 3(1) ${ }^{93}$ and 34(5), respectively. ${ }^{94}$

\section{Exceptions to Transparency (Privileged and Confidential Information)}

To alleviate the fear that reinforced transparency will result in the release of confidential information, almost all the arbitration rules under discussion have taken account of the protection of the privileged information. ICSID, e.g., provides rudimentary protection for privileged and confidential information. ${ }^{95}$ Marching forward, both the 2012 U.S. Model BIT $^{96}$ and the NAFTA ${ }^{97}$ employ the precise language and classify the information into several groups. It is not difficult to find that the UNCITRAL Rules almost reiterates the wordings of U.S. Model BIT and the NAFTA integrated them into its present text.

It is also not surprising that the UNCITRAL Rules on Transparency, to some extent, has combined the strengths of previous practices on transparency standards and blazed a new trail for an integral transparency mechanism. ${ }^{98}$

\section{A Comment on the Rules on Transparency and Transparency Convention}

Article 7 (Exceptions to transparency), subparagraph (2) of the Rules on Transparency set out the critical definition of "confidential or protected information." Although subparagraph (3) makes clear that a tribunal has the authority to determine whether a document is confidential or protected, this is undermined by subparagraph (2)(c) which states that information of the respondent to the arbitration designated as protected, is determined by its law. This is in contrast to earlier negotiation text versions of Article 7(2)(c), where such determinations would have been determined by the 
tribunal.

In effect, this clause implies that the tribunal has to turn to respondent's domestic law in ascertaining whether documents should be made public. In well-developed systems of access to government information, such as with the US Freedom of Information Act ("FOIA"), or the Access to Information Act ("ATIP") of Canada, this may not be problematic because there should be domestic remedies when government officials make mistakes on secrecy.

In the countries without due process mechanisms or a policy default to secrecy, Article 7 of the Rules could well force tribunals to apply laws contrary to the very transparency objectives of the new Rules on Transparency. State respondents may apply the same restrictive approach to the production of documents to the arbitration itself so that they would impede transparency and potentially violate the new rules.

Some members of the UNCITRAL negotiating group believed that the approach under Article 7(2)(c) of the Rules on Transparency could be "open to abuse." ${ }^{99}$ Especially, the view was offered in the October 2012 session of the UNCITRAL Working Group as follows:

\footnotetext{
Providing for mandatory application by a State of its national law in relation to information provided by it would permit a State to circumvent the object of the rules by introducing legislation precluding the disclosure of all information in investor-State disputes. In response, unanimous support was expressed for the proposition that it was not permissible for a State to adopt UNCITRAL Rules on Transparency and then use its domestic law to undermine the spirit (or the letter) of such rules. ${ }^{100}$
}

They compromise for the final version of Article 7(2)(c), to include provisions in Article 1 on the "discretion and authority of the tribunal" transparency objectives of the new rules and provide a mechanism for balancing confidentiality and transparency. Article 1(6) stated: "In the presence of any conduct, measure or other action having the effect of wholly undermining the transparency objectives of these rules, the arbitral tribunal shall ensure that those objectives prevail."

What if then a respondent State only partially undermines the transparency objectives of the rules? How will such a provision be applied in future by tribu- 
nals in the face of a respondent State maintaining secrecy? Will it be an important test for the effectiveness of the new UNCITRAL Rules on Transparency?

\section{Conclusion: The ImPlications OF THE UNCITRAL RULES ON TRANSPARENCY AND the Transparency Convention for China}

\section{A. To Launch a Transparency-oriented Reform}

\section{To Build a Government Ruled by Law}

As mentioned above, transparency reform will open a new world of investment arbitration, leading to less corruption, impartial awards and broader public scrutiny. Even if this reform originated from the urge of the international community for transparency, it would lead countries to change their legal environment substantially. Suppose a State is sued under the auspices of the UNCITRAL Arbitration Rules relating to the Rules on Transparency, the relevant documents concerning public interests would be available to the public, shedding light on the State's concealed misconducts. As is often referred, 'sunshine disinfects.' More or less, laymen have access to "the things that they have rights to know," which conduces to public's monitoring over political regime and promotes the construction of a government ruled by law. Going forwards, the improved transparency is in compliance with China's aspiration of building "A Government Ruled by Law." ${ }^{103}$ As the Fourth Plenary Session of the 18th Central Committee of the Chinese Communist Party was held with the "Rule of Law" as its theme, such a drive for transparency was expected to sweep over all administrative fields ${ }^{104}$ and, supposedly, legitimize or normalize governmental conduct in investment areas.

The transparency in IIA arbitrations may be instrumental to a more comprehensive perception of the State's investment environment. Where the investment environment is sound, stable and reliable, merchants will nose it and bring in a big bunch of capitals and technologies, thus fostering a virtuous investment circle. On the contrary, if the investment environment in the host country is chaotic, no investors may dare come. To put it differently, "The exposure of a government's inner workings and regulatory structures may impel states who hope to re- 
ceive an influx of foreign investment to act more accountably in accordance with international norms of good governance with regard to foreign investment."

\section{To Improve Domestic Laws in Information Protection}

The transparency-oriented reform necessitates a reassessment of the relevant laws and regulations. According to Article 7(2)(c) the Rules on Transparency, the host country may insist that its domestic laws be in the best interests of the nation and her nationals. If they continue to operate, however, China's laws and regulations such as Regulation of the People's Republic of China on the Disclosure of Government Information [中华人民共和国政府信息公开条例] (hereinafter Regulation of Disclosure of Government Information) and Law of the People's Republic of China on Guarding State Secrets [中华人民共和国保守国家秘密法] (hereinafter Law of Guarding State Secrets) will pose a big challenge to the transparency standards. "The outdated Law of Guarding State Secrets and the Regulation of Disclosure of Government Information have been incompatible with each other, resulting in the contradictions." ${ }^{, 106}$ What needs disclosure is kept secret, while what needs protection, revealed.

For China, it is necessary to calculate what areas shall be made public and to what extent they can be made public. A limited openness may disappoint the public and dissatisfy the aim of the transparency reform. It is imperative to research the possible areas for openness, like, e.g., making public the reasoning of all administrative actions.

\section{To Strive to Develop NGOS}

In this regard, NGOs should play a bigger role. Ever since US shrimps in WTO, ${ }^{107}$ amicus curiae has been introduced. Recently, third party participation in international disputes concerning public interest is upswing. Thus, the ISDS mechanism would have the room for amicus curiae briefs. As mentioned above, many NGOs have submitted amicus curiae briefs. It is matter of concern if China would foster NGOs in this field, which are now far behind those in developed countries like the US. For a more active engagement in global governance and IIA arbitrations in the future, however, China should facilitate professional NGOs. ${ }^{108}$ Above all, transparency standards in the IIA arbitration would help lay a solid foundation for China to have in place the rule of law. 


\section{B. Tune Transparency Standards to China's Strategy in IIAs Negotiations?}

\section{An Equilibrium between Host Country and Investors' Home Country}

For the past couple of years, China has acted as a dual player in both capital output and input. The 2014 World Investment Report has displayed that China maintained its position as the second largest recipient in the world, receiving in FDI influx of USD124 billion in 2013, only next to the US. ${ }^{109}$ When it comes to the Overseas Direct Investment ("ODI"), the volumes are remarkable, ranking the third in the world, accounting for USD101 billion in $2013 .{ }^{110}$ The outflows have been quite close to inflows. Speculatively, China will pay more attention to transforming a net recipient into a leading global flow contributor of foreign investment.

When China is the host State, she is willing to have more policy support as a developing country. As ODI rises, however, China is obliged to bear the responsibility of investors' home State and provide strong backups for her overseas investment. The interests of investors' home countries and host countries are, for most of the circumstances, in conflict. If transparency topics are raised in BIT or FTA negotiations, how could China respond to this conflict of interest?

Thereby, a question may arise on what influence the transparency standards will exert on host countries and investors, respectively. An in-depth exploration of the question is believed to help shape China's strategy for future negotiations of IIAs.

From the perspective of host countries, higher transparency standards serve public interests better and more effectively. Governments in host countries, however, would be reluctant to embrace transparency standards since openness might bring about extra political risks and pressure on the administration. Furthermore, once the arbitration is made available to the public, it will incur more investment claims against similar measures. It would be formidable.

When it comes to the investors, they "fear the forced disclosure of confidential business information, trade secrets, investment strategies and other sensitive information that could harm their business," ${ }^{111}$ even though the transparency standards will reduce the briberies and payment of success in the arbitrations. In fact, this is not all that bad. Generally, other investors may have easier access to the investment environment of the host country, which will enable them to make more rewarding choices. Furthermore, "virtually every system of domestic and 
international arbitration and litigation has additional safeguards for protecting privileged information, such as confidentiality orders focused on the nondisclosure of trade secrets."

In this light, higher transparency standards might do harm and good to both the host country and the investors. Even so, objectively speaking, "promoting transparency in arbitrations is more advantageous to the host country," 113 but provided that the host country employs a sound and complete domestic legal environment.

Since China is still a developing country, the gap between developed and developing countries shall not be blurred blindfold, particularly considering the distinctions among their respective legal environments. For the past 20 years, the number of IIAs as well as treaty-based arbitrations have been increasing. Just take Argentina as an example. The arbitrations almost dragged the country into a deadlock. Without a complete domestic legal system, not only de jure, but also de facto, the risks of being sued in the IIA arbitrations are fairly alarming for the host country.

In the event of conflicts, China might as well stand as a host country, especially in reaching its IIAs. Regardless of the host country or the investors, higher transparency standards can be welcomed. As for China, even faced with domestic challenges of transparency reform and legal systems, transparency standards shall be highlighted. The question is to combine its status quo with appropriate change, which is neither too large that might lead to incompatibility, nor too small that might prohibit the protection of host country's interests.

\section{The Transparency Standards in IIA Negotiations: A Strategy for China?}

As the Rules on Transparency and the Transparency Convention came into existence, another implication for China is to take transparency standards as a strategy for her future IIA negotiations. The authors would suggest that it is helpful to extrapolate the transparency standard from the following three aspects.

First, transparency can be used in negotiations in exchange of other concessions from the other contracting party because introducing the transparency standards is in the long-term interest of China.

Second, China can cogitate upon reservation clauses in the Transparency Convention considering that she has not fully equipped, but admittedly, transpar- 
ency is gaining momentum in various aspects. ${ }^{114}$ Pursuant to Articles 3.1, 3.2 and 4 of the Transparency Convention, reservations can be rendered at any time to minimize its adverse effect. ${ }^{115}$

Last but not least, in the course of negotiation, national security can be used as an exception to transparency standards. Even though the Rules on Transparency has been finally drafted, China could accord expansive interpretation of the exceptions to transparency in light of her domestic needs. Article 7.2 of the Rules has conferred the host country the discretions to decide some confidential information in correspondence to her domestic laws. China still plays a vigorous role in enriching its own information protection law, or even completing its security protection laws so that the essential security interests can be safeguarded. The national security exception is a good defense. ${ }^{116}$

\section{Prospects of China's Strategy in IIA Negotiations}

Notably, in the October 2010 compilation of comments by governments on the UNCITRAL's transparency in treaty-based investor-State arbitration, China rejected the transparency in investment arbitration. China submitted:

There is currently no such practice of treaty-based investor-State arbitration in China. Given the confidentiality of arbitration, we do not consider it appropriate to impose provisions of publicity and transparency on treaty-based settlement of investor-State investment disputes. ${ }^{117}$

However, this zero record was broken in May 2011, with the first claim against China by a Malaysian company. ${ }^{118}$ From this on, China is presumed to pay more heed to the IIA arbitrations and her attitudes towards transparency.

After pages of analysis on transparency and its implications, one more question remains: Will China refer to the UNCITRAL Arbitration Rules in the future IIAs texts? If so, will China make reservations on the application of the Rules on Transparency therein? It cannot be readily asserted if China could exclude the UNCITRAL Arbitration Rules in her IIA negotiations, considering that hundreds of BITs in the world have no reference to the UNCITRAL Rules. Still, a portion of the BITs, such as thirteen of Singapore's eighteen BITs, have done so. ${ }^{119}$ Nonetheless, whether China is likely to follow Singapore's pattern in its future IIA negotiations, particularly in the high-profile Sino-U.S. BIT negotiations, remains a mystery. 
In recent times, the Sino-US BIT negotiations have entered into a new phase with an exchange of BIT texts. ${ }^{120}$ Also, Sino-Korean FTA have almost been concluded and the Sino-Australian FTA and Sino-Norwegian FTA are forthcoming. ${ }^{121}$ In consideration of the secrecy in negotiations, transparency acceptance is not yet observed in these future IIAs. To be fair, at least for the present, there is no sign that China will delete transparency standards from the texts. Optimistically, it is anticipated that China may be open to the transparency standards in a proactive manner.

\section{REFERENCES}

1. E. Levine, Amicus Curiae in International Investment Arbitration: The Implications of an Increase in Third-Party Participation, 29 Berkeley J. InT'L L. 202 (2011).

2. See UNCTAD World Investment Report 2014 , available at http://unctad.org/en/PublicationsLibrary/wir2014_en.pdf (last visited on Feb. 11, 2015)

3. UNCTAD, Recent Development in Investor-State Dispute Settlement (2014), available at http://unctad.org/en/PublicationsLibrary/webdiaepcb2014d3_en.pdf (last visited on Feb. 11, 2015).

4. J. Maupin, Transparency in International Investment Law: The Good, the Bad, and the Murky, in Transparency in International Law 2 (A. Bianchi \& A. Peters eds. 2013).

5. See generally UNCTAD, International Investment Arrangements: Trends and Emerging Issues, available at http://www.unctad.org/en/doc/iteiit200511_en.pdf (last visited on Feb. 11, 2015).

6. The statistics recorded cases known from 1987 to 2013, since some cases were held inaccessible to the public knowledge. The statistics kept a relatively modest data considering the secrecy of arbitrations even in existence. See supra note 2, at 124.

7. A. Palma, NAFTA's Powerful Little Secret: Obscure Tribunals Settle Disputes, But Go Too Far, Critics Say, N.Y. Times (Mar. 11, 2001), § 3.

8. B. Kingsbury \& S. Schill, Investor-State Arbitration as Governance: Fair and Equitable Treatment, Proportionality and the Emerging Global Administrative Law, 5 (Institute for Int'l Law \& Justice, Working Paper, June 2009). See also J. Rosenau, Governance in the Twenty-first Century, 1 Global Governance 17 (1995).

9. Yu Keping, Introduction to Global Governance. 1 MarXism \& Reality 4 (2002).

10. J. Ribeiro, Trends of International Arbitration: The Role and Future Work of UNCITRAL and of its Regional Centre for Asia and the Pacific, available at http://www.uncitral.org/ pdf/english/TAC/RCAP/Interview_KCAB_Journal.PDF (last visited on Feb. 11, 2015)

11. L. Finkelstein, What is Global Governance? 1 Global Governance 367 (1995).

12. Typical cases that implicate amicus curiae may refer to as follows: Methanex Corp. v. 
United States of America (arbitrated under NAFTA); UPS v. Canada (arbitrated under NAFTA); Biwater Gauff (Tanzania) Ltd. v. United Republic of Tanzania (arbitrated under ICSID Rules) and AES Summit Generation Ltd.; and AES - Tisza Eromu Kft. v. Republic of Hungary (arbitrated under Energy Chapter Treaty Rules).

13. S. Santivasa, The NGO's Participation in the Proceedings of the International Court of Justice, 2 J. East Asia \& InT'L L. 377 (2012).

14. ICSID Arbitration Rules: Rules of Procedure for Arbitration Proceedings (2006), rule 50(1)(c)(iii).

15. Linqin Yang, Research on the Transparency Issues in the International Investment Arbitration, 3 HLJ F. Econ. Rel. \& TRAdE (2008).

16. Black's Law Dictionary (9th ed.), at 1638.

17. Oxford Law Dictionary (5th ed.), at 505.

18. Supra note 1, at 204. See also P. Malanczuk, Confidentiality and Third-Party Participation in Arbitration Proceedings under Bilateral Investment Treaties, Contemp. Asia ARB. J. 187-9 (2008); D. Magraw Jr. \& N. Amerasinghe, Transparency and Public Participation in Investor-State Arbitration, ILSA J. INT'L \& Comp. L. 354 (2009).

19. Malanczuk, id. at 187. See also supra note 1, at 204; Jianlong Yu, On the Transparency Principles of International Investment Arbitration [论国际投资仲裁的透明度原则], 9 JINAN J. (PHIL. \& Soc. SCI.) [暨南学报 (哲学和社会科学版)] (2012).

20. North American Free Trade Agreement ("NAFTA"), reprinted in 32 I.L.M. 289, art. 1137(4) (1993).

21. See Notes of Interpretation of Certain Chapter 11 Provisions (NAFTA Free Trade Commission), available at http://www.naftaclaims.com./commissionfiles/NAFTA_Comm_1105_ Transparency.pdf art. 1 (last visited on Feb. 11, 2015).

22. Id. art. 2.

23. N. Bernasconi-Osterwalder \& L. Johnson, Transparency in the Dispute Settlement Process: Country best prices. International Institute for Sustainable Development, IISD BEST Practice Series, available at http://www.iisd.org/publications/transparency-disputesettlement-process-country-best-practices (last visited on Feb. 11, 2014)

24. It reads: "All documents submitted to, or issued by, the Tribunal shall be publicly available, unless the disputing parties otherwise agree, subject to the deletion of confidential information." See Canada Model FIPA, available at http://www.treaty-accord.gc.ca/texttexte.aspx?id=105176\&lang=eng (last visited on Feb. 11, 2015)

25. See U.S. Model BIT (2004), available at https://ustr.gov/archive/assets/Trade_Sectors/ Investment/Model_BIT/asset_upload_file847_6897.pdf

26. Yu, supra note 9.

27. For open hearings, see ICSID Arbitration Rules art. 32.2. For amicus briefs, see id. art. 37; for publication of awards, see id. art. 48.

28. S. Levander, Resolving "Dynamic Interpretation": An Empirical Analysis of the UNCIT- 
RaL Rules on Transparency, 52 Colum. J. Transnat'l L. 518 (2014). For the two cases mentioned, see Amco Asia Corp. v. Republic of Indonesia, ICSID Case No. ARB/81/1, Decision on Request for Provisional Measures (Dec. 9, 1983); Biwater Gauff Ltd. v. United Republic of Tanzania, ICSID Case No. ARB/05/22, Procedural Order No. 3 (Sept. 29, 2006).

29. Levander, $i d$.

30. See Report of the UNCITRAL 41st Session, ๆ 13, U.N. Doc. A/63/17 (June 16 - July 3, 2008), available at http://www.uncitral.org/uncitral/en/commission/sessions/41st.html (last visited on Feb. 24, 2015).

31. Id.

32. As for the adoption of UNCITRAL Rules on Transparency, see, e.g., UNCITRAL, Report of Working Group II (Arbitration and Conciliation) on the work of its fiftyeighth session, I12, available at http://www.uncitral.org/uncitral/en/uncitral_texts/ arbitration/2014Transparency.html (last visited on Feb. 23, 2015). See also U.N. Doc. A/ CN.9/765 (Feb. 13, 2013)

33. UNCITRAL Arbitration Rules art. 1, ๆ 4, available at http://www.uncitral.org/uncitral/en/ uncitral_texts/arbitration/2010Arbitration_rules.html (last visited on Feb. 13, 2015)

34. For the debates over application of IIAs, see Report of Working Group II (Arbitration and Conciliation) on the work of its fifty-fifth session, 9 甲 18-30, U.N. Doc. A/CN.9/736 (Oct. 17, 2011).

35. See UNCITRAL, Report of the 47th session of United Nations Commission on International Trade Law, U.N. Doc. A/69/17 (July 7-18, 2014), I 14, available at http://www. un.org/ga/search/view_doc.asp?symbol=A\%2F69\%2F17\&Submit=Search\&Lang=E (last visited on Feb. 24, 2015).

36. It will be submitted to the United Nations General Assembly for final consideration and adoption. According to the draft convention on transparency, it is open for signature on March 7, 2015.

37. UNCTAD, Transparency: UNCTAD Series on Issues in International Investment Agreements II, (New York and Geneva) 7-8 (2012).

38. Id. at 75-7.

39. Supra note 32, ๆ 20-7. See generally UNCITRAL Working Group II: Settlement of Commercial Disputes: Preparation of a Legal Standard on Transparency in Treaty-based Investor-State Arbitration, ๆ 7, U.N. Doc. A/CN.9/WG.II/WP.176 (Nov. 30, 2012); UN Commission on International Trade Law Secretariat, Report of Working Group II on the work of its fifty-ninth session, $953-8$, U.N. Doc. A/CN.9/794 (Sept. 26, 2013).

40. U.N. Doc. A/CN.9/794 (Sept. 26, 2013).

41. Id.

42. The US and Canada hoped to maintain the high standard of transparency in conformity with NAFTA practices. See supra note 4, at 10. 
43. Rachel Davis, Special Representative of the U.N. Secretary-General on the Issue of Human Rights and Transnational Corporations and Other Business Enters. Statement to the UNCITRAL Working Group II (Arbitration and Conciliation) (Feb. 7-11, 2011), available at http://www.business-humanrights.org/media/documents/ruggie-statement-uncitralworking-group-ii.pdf (last visited on Feb. 13, 2015).

44. J. Lee, UNCITRAL's Unclear Transparency Instrument: Fashioning the Form and Application of a Legal Standard Ensuring Greater Disclosure in Investor-State Arbitrations, 33 Nw. J. INT'L L. \& Bus. 468 (2013).

45. See U.N. Commission on International Trade Law Secretariat, Settlement of Commercial Disputes: Preparation of A Legal Standard on Transparency in Treaty-Based Investor-State Arbitration, ๆ 28, U.N. Doc. A/CN.9/WG.II/WP.162 (Dec. 9, 2010).

46. UNCITRAL Rules on Transparency art. 1, ๆ 2(b). See generally UNCITRAL: Settlement of Commercial Disputes: Applicability of the UNCITRAL Rules on Transparency to the Settlement of Disputes arising under Existing Investment Treaties, 16 , U.N.Doc. A/CN.9/784 (Mar. 6, 2013); UNCITRAL: Settlement of Commercial Disputes: Application of the UNCITRAL Rules on Transparency in Treaty-based Investor-State Arbitration to Existing Investment Treaties-Draft Convention, qा 7 \& 12, U.N.Doc. A/CN.9/WG.II/ WP.179 (Aug. 1, 2013).

47. UNCTRAL Rules on Transparency art. 1, $₫ 2(b)$.

48. See the official website of MOC, available at http://www.gov.cn/gzdt/2012-09/10/ content_2220644.htm (last visited on Feb. 15, 2015).

49. U.N.Doc. A/CN.9/WG.II/WP.179 (Aug. 1, 2013), ๆ 7. See also supra note 45.

50. U.N. Commission on International Trade Law Secretariat, Report of the Working Group II Fifty-Fourth Session, 9 39, U.N. Doc. A/CN.9/717 (Feb. 25, 2011).

51. See U.N. Commission on International Trade Law Secretariat, Settlement of commercial disputes: Draft convention on transparency in treaty-based investor-State arbitration, U.N.Doc. A/CN.9/812 (Mar. 4, 2014).

52. Id.

53. Transparency Convention arts. 3(1)(a) \& 3(1)(b).

54. Id. art. 2(1).

55. U.N. Doc. A/CN.9/794 (Sept. 26, 2013), ๆ 26 \& ๆๆ 104-14.

56. $I d . \rrbracket 24$.

57. Supra note 51.

58. U.N. Commission on International Trade Law Secretariat, Settlement of commercial disputes: Preparation of a legal standard on transparency in treaty-based investor-State arbitration - Comments of arbitral institutions on the interplay between the draft rules on transparency and their institutional rules, U.N. Doc. A/CN.9/WG.II/WP.173 (July 19, 2012).

59. Reservations were discussed in details in session $\mathrm{E}$.

60. U.N. Doc. A/CN.9/794 (Sept. 26, 2013), ๆ 32. 
61. Supra note 51.

62. Supra note $69, \uparrow 119$.

63. Transparency Convention art. 3.

64. Supra note 45.

65. Rules on Transparency art. 3.1

66. Id. art. 2.

67. Id. art. 7.

68. Id. art. 6.

69. Id. art. 7.

70. See generally Jun Zhao \& Yun Liu, The Transparency Reform in International Investment Arbitration and China's Reactions, 44 J. Zhejiang U. (Human. \& Soc. Sci.) [浙江大学学报 (人文社会科学版)] (2014). See also supra note 50, ๆ 1.

71. Zhao \& Liu, id.

72. NAFTA Notes of Interpretation of Certain Chapter 11 Provisions (NAFTA Free Trade Commission) art. 2(b).

73. See UNCITRAL: Settlement of Commercial Disputes: Preparation of a Legal Standard on Transparency in Treaty-based Investor-State Arbitration-Note by the Secretariat regarding the establishment of a repository of published information (registry), U.N.Doc. A/CN.9/ WG.II/WP.177 (Dec. 2012).

74. Zhao \& Liu, supra note 70. See also id. $\mid 2$.

75. Rules on Transparency, art. 3.1.

76. ICSID Administrative and Financial Regulations, reg. 22(2).

77. 2012 U.S. Model BIT, art. 29(1), available at https://ustr.gov/sites/default/files/BIT\%20 text\%20for\%20ACIEP\%20Meeting.pdf (last visited on Feb. 17, 2015).

78. Rules on Transparency, art. 6.

79. 2012 U.S. Model BIT art. 29(2).

80. See Methanex Corp. v. United States Final Award (Aug. 3, 2005), ๆ 8, available at http:// www.naftaclaims.com./disputes/usa/Methanex/Methanex_Final_Award.pdf (last visited on Feb. 14, 2015).

81. See Procedural Order No. 11, July 9, 2007, available at http://www.naftaclaims.com./disputes/usa/Glamis/Glamis-USA-Tribunal-Order_11.pdf (last visited on Feb. 14, 2015).

82. F. Covey, Amicus Curiae: Friend of the Court, IX De Paul L. Rev. 30 (1959).

83. See State v. Finley, 242 Minn. 288, 294, 295, 64 N.W.2d 769, 773 (1954). See also id.

84. Aguas Argentinas, S.A. Suez, Sociedad General de Aguas de Barcelona, S.A. and Vivendi Universal, S.A., v. Argentina, Order in Response to a Petition for Transparency and Participation as Amicus Curiae, ICSID Case No. ABR/03/19 (May 19, 2005), q 16, available at https://icsid.worldbank.org/apps/ICSIDWEB/cases/Pages/casedetail. aspx?CaseNo=ARB/03/19 (last visited on Feb. 14, 2015)

85. 2006 ICSID Arbitration Rules, rule 37(2). See also 2006 Additional Facility Rules, art. 
41(3).

86. These factors include: (a) whether the submission will assist the tribunal determine a factual or legal issue by providing a perspective that differs from the parties to the dispute; (b) whether the submission is within the scope of the dispute; (c) whether the non-party has a significant interest in the proceeding. See id.

87. Canada Model FIPA art. 39.

88. 2012 U.S. Model BIT art. 28.

89. Rules on Transparency art. 4.

90. Supra note 34, ๆ 87.

91. See Methanex Corp. v. United States, Final Award, Aug. 3, 2005, ๆ 31, available at http:// www.naftaclaims.com./disputes/usa/Methanex/Methanex_Final_Award.pdf (last visited on Feb. 14, 2015).

92. ICSID Arbitration Rules, rule 48(4). See also ICSID Additional Facility Rules, art. 53(3).

93. Rules on Transparency, art. 3(1).

94. UNCITRAL Arbitration Rules, art. 34(5).

95. ICSID Arbitral Rules, rule 32(2). The second sentence reads: "The Tribunal shall for such cases establish procedures for the protection of proprietary or privileged information."

96. 2012 U.S. Model BIT art. 29.

97. North American Free Trade Agreement Notes of Interpretation of Certain Chapter 11 Provisions, art. 2(b) i, ii \& iii (NAFTA Free Trade Commission).

98. Levander, supra note 28, at 539.

99. Supra note 34, ๆ 127. See also supra note 32, ๆๆ 59-62.

100. See UNCITRAL, Report of Working Group II (Arbitration and Conciliation) on the work of its fifty-seventh session (Oct. 2012), \ 103, U.N. Doc. A/CN.9/760 (Oct. 12, 2012).

101. Supra note 32, ๆๆ 67-75.

102. See generally supra note 4.

103. The Fourth Plenary Session of the 18th Central Committee of the CCP has waged an anticorruption campaign and promoted transparency and openness in all administrative areas. See the Communique of the Fourth Plenary Session of the 18th Central Committee of the CCP, available at http://news.xinhuanet.com/ttgg/2014-10/23/c_1112953884.htm (last visited on Feb. 14, 2015)

104. Id.

105. Levander, supra note 28, at 515.

106. Xixin Wang, Institutional Practices and External Environment of Information Publicity An Inspection from the Institutional Environment of Governmental Information Publicity, 2 J. Nankai U. (Philosohpy, Literature \& Soc. Sci.)] [南开学报（哲学社会科学版)] (2011).

107. Zhao \& Liu, supra note 70.

108. See generally Danni Liang, A Study on the Transparency of International Investment Arbitration: The ICSID Arbitration Rules 2006 and the Revision of UNCITRAL Arbi- 
tration Rules, [国际投资争端仲裁程序透明度研究 - 从 《ICSID仲裁规则》(2006)和 《UNCITRAL仲裁规则 (修订草案)》谈起]17 [Chinese] J. INT'L ECON. L. [国际经济法 学刊] (2010); Mengxing Zhang, Research on the Transparency Problem in Investor-State Arbitration Mechanism [投资者与国家仲裁机制中的透明度问题研究], 9 LEGALITY VISION [法制博览] (2013); Zhao \& Liu, supra note 70.

109. Supra note 2, at 15.

110. Id.

111. Levander, supra note 28 , at 514.

112. Id.

113. Zhao \& Liu, supra note 70, at 158.

114. Supra note 4.

115. Transparency Convention art. 4.

116. Rules on Transparency art. 7.5.

117. See U.N. Commission on International Trade Law Secretariat, Settlement of Commercial Disputes: Compilation of Comments by Governments on the UNCITRAL's Transparency in Treaty-based Investor-State Arbitration, U.N. Doc. A/CN.9/WG.II/WP.159/Add.1 (Aug. 4, 2010)

118. See Ekran Berhad, v. People's Republic of China, ICSID Case No. ARB/11/15 (May 24, 2011), available at https://icsid.worldbank.org/apps/ICSIDWEB/cases/Pages/casedetail.aspx? CaseNo=ARB/11/15 (last visited on Feb. 17, 2015). Up until now, there have been two cases in ICSID concerning China as a respondent, the other is Ansung Housing Co., Ltd. v. People's Republic of China, ICSID Case No. ARB/14/25 (Nov. 4, 2014), available at https://icsid.worldbank.org/apps/ICSIDWEB/cases/Pages/casedetail. aspx? $\mathrm{CaseNo}=\mathrm{ARB} / 14 / 25$ (last visited on Feb. 14, 2015).

119. Levander, supra note 28, at 530.

120. Staff writer, Sino-US Investment Protection Agreements Re-boost Pragmatic Cooperation in accordance with Global Economic Growth [中美投资保护协定再获进展 务实合作助 力全球经济增长] (available only in Chinese), XINHUA News, Dec, 16, 2014, available at http://news.xinhuanet.com/world/2014-12/16/c_1113667245.htm (last visited on Feb. 12, 2015).

121. See the official website of MOFCOM, available at http://fta.mofcom.gov.cn (last visited on Feb. 15, 2015). 